\title{
Integration of HOTS-Based Questions on the Theme "The Beauty of Togetherness" through Fun Thinkers Learning Media for Grade IV Elementary School Students
}

\author{
Ni Komang Ayu Indah Pranyani*, I Gusti Ayu Tri Agustiana², Alexander \\ Hamonangan Simamora ${ }^{3}$
}

1,2,3 Universitas Pendidikan Ganesha, Singaraja, Indonesia

\section{ART ICLE IN F O}

\section{Article history:}

Received March 20, 2021

Revised March 21, 2021

Accepted June 28, 2021

Available online August 25, 2021

\section{Kata Kunci:}

HOTS, Media Pembelajaran, Fun Thinkers

Keywords:

HOTS, Learning Media, Fun Thinkers

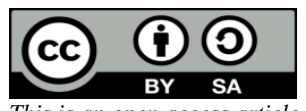

This is an open access article under the CC BY-SA license.

Copyright (C) 2021 by Author. Published by Universitas Pendidikan Ganesha.

\begin{abstract}
A B S T RA K
Minimnya penggunaan media pembelajaran yang digunakan untuk penyampaian materi sehingga menyebabkan siswa sulit memahami materi. Penelitian ini bertujuan untuk mengembangkan media fun thinkers berbasis soal HOTS untuk siswa SD kelas IV pada tema 1 indahnya kebersamaan. Pengembangan dilakukan dengan berpedoman pada prosedur model ADDIE. Subjek yang terdapat pada penelitian pengembangan ini adalah media fun thinkers berbasis soal HOTS untuk siswa sekolah dasar kelas IV tema 1 indahnya kebersamaan sedangkan objek pada penelitian ini adalah validitas media fun thinkers yang dikembangkan. Metode penelitian pengembangan ini adalah metode analisis statistik kualitatif dan kuantitatif. Pengumpulan data yang digunakan yaitu metode kuisioner dengan instrumen pengumpulan data berupa rating scale dengan pemberian instrumen penilaian kepada 2 orang ahli materi soal, 2 orang ahli media, 2 orang respon praktisi, dan 10 orang siswa sebagai respon. Data yang diperoleh dihitung menggunakan rumus mean untuk mengetahui rata-rata skor validitas media. Rata-rata skor validitas media fun thinkers berbasis soal HOTS dari segi ahli materi/asesmen sebesar 4.79 dengan kriteria sangat valid, dari segi ahli media sebesar 4.43 dengan kriteria sangat valid, dari segi respon praktisi sebesar 4.63 dengan kriteria sangat valid, dan dari segi respon siswa sebesar 4.95 dengan kriteria sangat valid. Berdasarkan analisis yang dilakukan bahwa media fun thinkers berbasis soal HOTS untuk siswa SD kelas IV tema 1 indahnya kebersamaan yang dikembangkan valid dan layak digunakan dalam proses pembelajaran.
\end{abstract}

\section{A B S T R A C T}

The lack of use of learning media used for delivering material makes it difficult for students to understand the material. This study aims to develop media for fun thinkers based on HOTS questions for fourth grade elementary school students on theme 1, the beauty of togetherness. The development is carried out based on the ADDIE model procedure. The subjects in this development research are media fun thinkers based on HOTS questions for elementary school students grade IV theme 1 the beauty of togetherness while the object in this study is the validity of the media fun thinkers developed. This development research method is a qualitative and quantitative statistical analysis method. The data collection used is a questionnaire method with data collection instruments in the form of a rating scale by giving assessment instruments to 2 subject matter experts, 2 media experts, 2 practitioner responses, and 10 students as responses. The data obtained was calculated using the mean formula to determine the average media validity score. The average validity score of media fun thinkers based on HOTS questions in terms of material/assessment experts is 4.79 with very valid criteria, in terms of media experts it is 4.43 with very valid criteria, in terms of practitioner responses it is 4.63 with very valid criteria, and in terms of response students of 4.95 with very valid criteria. Based on the analysis conducted, the media for fun thinkers based on HOTS questions for elementary school students in grade IV, theme 1, the beauty of togetherness developed is valid and suitable for use in the learning process.

\section{INTRODUCTION}

The way students learn in 21st Century learning has changed (Lawrence et al., 2020; Seruni et al., 2019; Trilling \& C., 2009; Wisada et al., 2019). In carrying out the learning process students are required to be able to develop knowledge in the context of learning. Reflecting on the 21st Century, especially the 2013 Curriculum, emphasizes students to learn through good examples, applications, and real-world experiences (Citrawathi et al., 2016; Winangun, 2020). The 21st century emphasizes learning skills and innovating as well as collaborating in creating a problem solving in student learning (Bialik et al., 2015; Tirri et al., 2017; Wisada et al., 2019). The four pillars of 21st Century learning include: (1) communication, (2) collaboration, (3) critical thinking, and (4) creativity.(Chong et al., 2016; Duriawati et 
al., 2020; Hajiyakhchali, 2013; Selman \& Jaedun, 2020). Learning in the 2013 curriculum also emphasizes students' higher-order thinking skills that must be honed and developed. In elementary school students, students have such great curiosity. With their abilities, students can try and practice higher-order thinking skills according to the demands of the 2013 Curriculum. In higher-order thinking skills, students learn not only abstract imagination, memorization, in learning, but also train students to be more active in applying, analyzing, and connecting learning with train higher order thinking skills (Agustihana \& Suparno, 2018; Budiman \& Jailani, 2014). Higher order thinking skills are the stages of expanding the mind that a person must have when meeting new challenges (Kurniati et al., 2016; Widihastuti \& Suyata, 2014).

Learning media is a tool that students can use to get new information and knowledge to understand the learning materials provided by the teacher. Basically, the media is used as a tool that can convey messages in the learning process that is being carried out (Fanny \& Suardiman, 2013). Media means an introductory or intermediary message that can channel information to students (Astra et al., 2020; Suryatin \& Sugiman, 2019). In modern times, learning media have also experienced developments and changes. Teachers should be able to develop innovative learning media and create a more active learning atmosphere so that basically learning will be difficult to understand and understand if there is no learning media. The use of learning media during a pandemic like this cannot be carried out properly and optimally (Ilsa et al., 2020; Primasari \& Supena, 2020). The existence of limited facilities and infrastructure owned by students also greatly determines the learning process. In addition, the use of monotonous learning media, lack of creativity and innovation of teachers in developing learning media is one of the inhibiting factors for achieving optimal learning so that learning becomes teacher-centered. Thus, causing students to participate less actively, get bored quickly, and unable to practice their thinking skills. In addition, teachers still use the lecture method which makes students bored and less enthusiastic in participating in learning.

Expectations in the world of education are students are able to think critically, creatively, actively and can participate in 21st century learning, namely high-level thinking. However, in reality, the learning process like this teacher still uses irrelevant learning media. When learning activities the teacher only relies on the content of the material and the questions in the teacher and student handbooks (Astra et al., 2020; Rehusisma et al., 2017). In addition, students also have difficulty in understanding the material taught by the teacher. When explaining, the teacher only shows monotonous learning video media so that this can affect the activity and quality of learning (Muyaroah \& Fajartia, 2017; Vince \& Muhtadi, 2019). So, teachers should be able to utilize learning media that are relevant and in accordance with the characteristics of students in the delivery of learning. One of the appropriate efforts that can be done regarding this problem is to develop media for fun thinkers based on HOTS questions.

Several relevant previous studies have examined the effectiveness of using media fun thinkers based on HOTS questions. The first research shows that the use of fun thinkers media can improve students' creative thinking skills in learning in elementary school (Agustiana et al., 2020; Riani et al., 2019). Furthermore, the second study also showed similar results. The use of fun thinkers media plays a very important role in improving vocabulary mastery skills for deaf children at SLB Wiyata Dharma Sleman (Kurniawati, 2017). Then, another study stated that the fun thinkers flash card media was effectively used as a supporter of scientific learning for elementary school students (Jummita et al., 2021; Saroh, 2016). Other research, developing HOTS-based media on thermodynamic materials (Agustihana \& Suparno, 2018). Based on these studies, it can be seen that so far there has been no research that has conducted the development of fun thinkers media that is integrated with HOTS-based questions, especially in learning in elementary schools. Therefore, the novelty of this research is to integrate media fun thinkers with practice questions based on HOTS. This study aims to develop media for fun thinkers based on HOTS questions for fourth grade elementary school students on theme 1, the beauty of togetherness. The integration of HOTS-based questions in fun thinkers media can have implications for increasing students' higher-order thinking skills.

\section{METHOD}

This research is a type of development research (Research and Development/RnD) (Sugiyono, 2018). The product developed in this research is a learning media called Fun Thinkers which is based on HOTS questions. The development is done by adapting the ADDIE model. The selection of this model is carried out on the basis of a systematic model that is suitable for use as an effort to overcome learning problems related to learning resources, and is adapted to the needs and characteristics of students (Tegeh et al., 2015). The stages that are passed in the process of developing learning media by adapting the ADDIE model include the analyze, design, development, implementation, and evaluation stages. However, 
in this study, the implementation phase (effectiveness testing/large group trials) was not carried out due to the Covid-19 pandemic. The stages of development are presented in Figure 1.

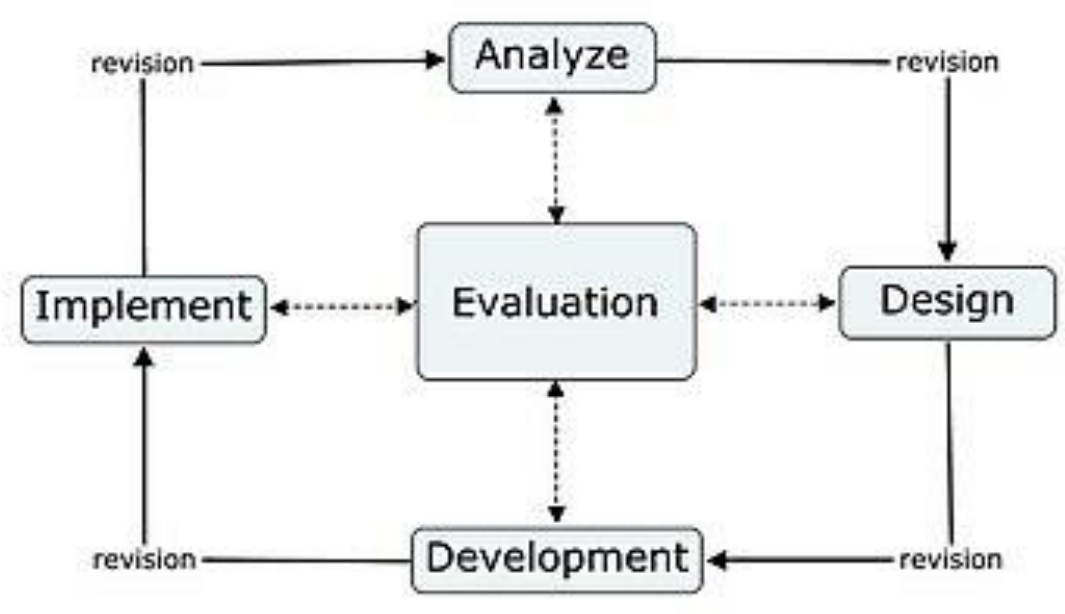

Figure 1. Stages of ADDIE Development Model (Tegeh et al., 2015)

The subjects in this development research are media fun thinkers based on HOTS questions for elementary school students in grade IV Theme 1 The Beauty of Togetherness. While the object in this study is the validity of the learning media developed, namely the media for fun thinkers based on HOTS questions on Theme 1 The Beauty of Togetherness in Class IV Elementary School. The parties involved in the process of testing the validity of the developed media include 2 material and assessment experts, 2 media experts, 2 practitioners, and 10 students as respondents for small group trials. Data collection in this study was carried out using the non-test method, namely by using an instrument in the form of a questionnaire sheet. Questionnaire sheets were used to measure and assess the validity of the product developed from the results of reviews conducted by material and assessment experts, media experts, practitioners, and student responses during small group trials. The instrument grid is presented in Table 1.

Table 1. Expert Validation Instrument Grid

\begin{tabular}{|c|c|c|}
\hline Aspect & Indicators & References \\
\hline \multicolumn{3}{|c|}{ A. Content and Assessment Expert } \\
\hline $\begin{array}{l}\text { Language } \\
\text { Usage }\end{array}$ & a. Quality of Language use & $\begin{array}{l}\text { (Kusumawardhana, } \\
\text { 2014) }\end{array}$ \\
\hline \multirow[t]{5}{*}{$\begin{array}{l}\text { Question } \\
\text { content }\end{array}$} & $\begin{array}{l}\text { a. Clarity and completeness of } 2013 \text { curriculum identity } \\
\text { on Fun Thinkers media media }\end{array}$ & \\
\hline & $\begin{array}{l}\text { b. The relevance of the question material to basic } \\
\text { competencies }\end{array}$ & \\
\hline & c. The relevance of the question material to the indicator & \\
\hline & $\begin{array}{l}\text { d. The relevance of the question material to the level of } \\
\text { student development }\end{array}$ & \\
\hline & $\begin{array}{l}\text { e. The relevance of the question material to the HOTS } \\
\text { level }\end{array}$ & \\
\hline \multicolumn{3}{|c|}{ B. Learning Media Expert } \\
\hline \multirow[t]{5}{*}{ Media design } & a. Media cover design & (Andriawan, 2015) \\
\hline & b. Image quality displayed & \\
\hline & c. The clarity of the displayed text & \\
\hline & d. Media display & \\
\hline & e. Layout & \\
\hline Language & a. Quality of language use & \\
\hline Usage & & \\
\hline Practicality & $\begin{array}{l}\text { a. Media practicality } \\
\text { b. Clarity of media usage }\end{array}$ & \\
\hline
\end{tabular}




\begin{tabular}{llll}
\hline \multicolumn{2}{c}{ Aspect } & \multicolumn{1}{c}{ Indicators } & References \\
\hline \multicolumn{2}{c}{ C. Practitioner } & & (Giyanti, 2018) \\
\hline Media serving & a. & Media technical quality & \\
Media quality & a. & Quality of content in the media & \\
& b. & HOTS-based question quality & \\
& c. & Instructional quality & (Saroh, 2016) \\
\hline \multicolumn{2}{c}{ Student Response } & \\
Question & a. & Retention of material & \\
Media usage & a. & Ease of using media in learning & \\
\hline
\end{tabular}

Data analysis techniques used in the development of this media include quantitative descriptive analysis and qualitative descriptive analysis. Qualitative descriptive statistical analysis methods in development research are related to processing words or sentences in the form of responses, criticisms, suggestions, input, and reviews of learning experts resulting from an object of research (Agung, 2014; Sugiyono, 2018). The results of the analysis will be used to improve the learning media developed in the research. Quantitative descriptive analysis technique is used to process research data obtained through a questionnaire in the form of a score. Furthermore, the average score that has been obtained is adjusted to the assessment criteria. The evaluation criteria for the validation results are represented in Table 2.

Table 2. Media Validity Assessment Criteria

\begin{tabular}{ccl}
\hline Score Interval & Rating Category & \multicolumn{1}{c}{ Decision } \\
\hline $4,21 \leq \mathrm{Va}<5,00$ & Very Valid & Can be used without revision \\
$3,41 \leq \mathrm{Va}<4,20$ & Valid & Usable with minor revisions \\
$2,61 \leq \mathrm{Va}<3,40$ & Enough & Can be used with multiple revisions \\
$1,81 \leq \mathrm{Va}<2,60$ & Not enough & Can't be used yet and still need consultation \\
$1,0 \leq \mathrm{Va}<1,80$ & Bad & Can not be used and must be reviewed and a total revision \\
\hline
\end{tabular}

(Arikunto, 2014)

\section{RESULT AND DISCUSSION}

\section{Result}

\section{Analyze Stage}

At this stage, a needs analysis is carried out to determine the needs of teachers and students in the learning process. This needs analysis was marked by giving questionnaires to teachers and students about the needs of elementary school students in learning the 2013 Curriculum. In developing a theme book that is packaged into the HOTS question-based fun thinkers media, it is supported by data on the distribution of questionnaires conducted in Gugus II Kecamatan Buleleng with a total of 9 teachers who stated that $91 \%$ of teachers strongly agree if the theme book is developed into fun thinkers media so that it can assist teachers in delivering learning and $9 \%$ of teachers agree if the theme book is developed and packaged into HOTS question-based fun thinkers media. The use of media fun thinkers based on HOTS questions can help students practice higher-order thinking skills. In addition, media fun thinkers based on HOTS questions help students to learn more effectively in practicing higher order thinking skills.

Based on the results of the questionnaire conducted on the fourth grade teacher of Gugus II Kecamatan Buleleng, the teacher stated that in the learning process in the classroom students only used student textbooks provided by the school and the use of learning videos on theme 1 the beauty of togetherness. Especially for learning theme 1, the beauty of togetherness, there is no special media that is used or discusses theme 1, the beauty of togetherness to help the teaching and learning process. The availability of media is very limited, the absence of special media used in theme 1 the beauty of togetherness can lead to a sense of laziness in learning, lack of enthusiasm, and lack of motivation in carrying out the learning process. From these problems, the solution that can be given is to develop themes into HOTS questions that can train students' thinking skills and package them in the form of media fun thinkers based on HOTS questions.

\section{Design Stage}

The learning media designed at this stage are media fun thinkers based on HOTS questions on theme 1 , the beauty of togetherness which is intended for grade IV elementary school. which exists. Media fun thinkers based on HOTS questions that were created and developed have a paper size of $21 \mathrm{~cm} \times 29.7$ 
$\mathrm{cm}$ and has a total of 31 pages. This HOTS question-based fun thinkers media uses art paper and glossy paper in its manufacture so that it is not easily torn and damaged. The results of the design of media fun thinkers based on HOTS questions are presented in Figure 2 and Figure 3.

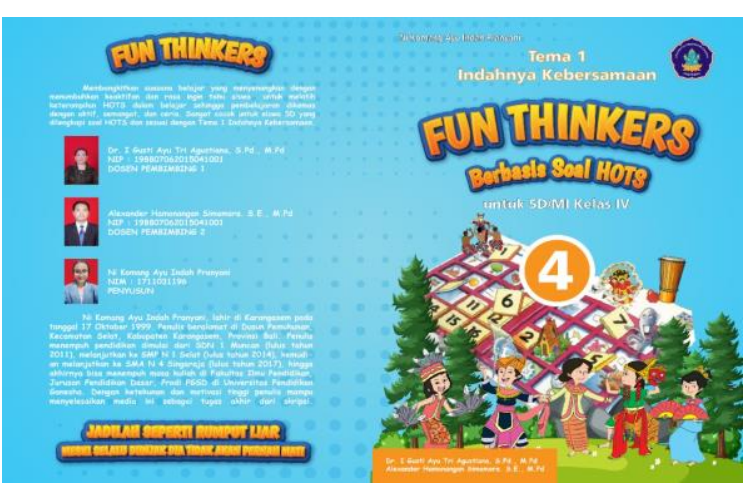

Figure 2. Cover

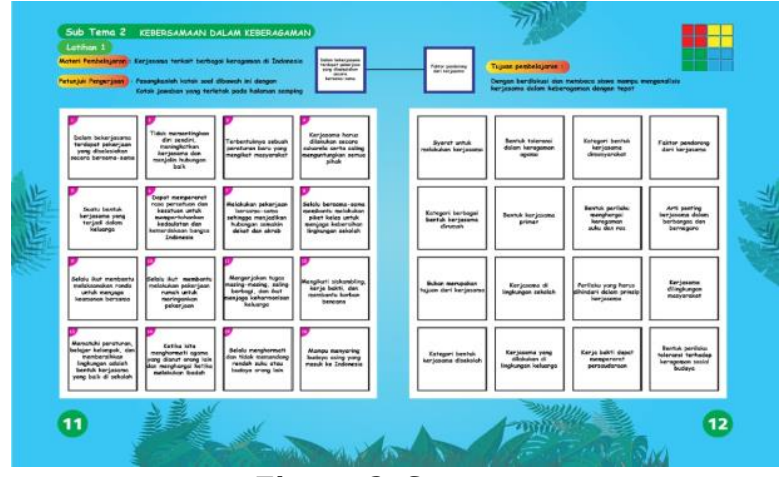

Figure 3. Contents

\section{Development Stage}

At this stage, a series of media development processes for fun thinkers based on HOTS questions are carried out on theme 1, the beauty of togetherness which is intended for the fourth grade of elementary school. The development is carried out through testing the validity of the media that has been designed previously. The validity test is carried out to get comments, suggestions, and input from experts and practitioners regarding the products that have been made. The comments, suggestions, and inputs are presented in Table 3.

Table 3. Comments, Suggestions, and Feedback

\begin{tabular}{cl}
\hline No. & \multicolumn{1}{c}{ Comments, Suggestions and Feedback } \\
\hline 1 & $\begin{array}{l}\text { The media that has been made is appropriate, it's just that there are some editorial questions } \\
\text { that need to be improved. }\end{array}$ \\
2 & $\begin{array}{l}\text { Instructions for use complete with colors according to the original image. In KD and indicators } \\
\text { make one column, look at the proportion of writing, give numbering in the question box, for }\end{array}$ \\
& $\begin{array}{l}\text { questions in the form of pictures, give names to the pictures to make them clearer and check } \\
\text { each answer key for each question. }\end{array}$ \\
3 & $\begin{array}{l}\text { Improved layout so that text or images are not lost or cut off when printed } \\
4\end{array}$ \\
The use of color in the background is made softer so that the information provided can be read \\
clearly.
\end{tabular}

Based on comments, suggestions, and input from material experts, the question states that the instructions for use are complete with colors according to the original image. In KD and indicators make one column, look at the proportions of writing, give numbering in the question box, for questions in the form of pictures, give names to the pictures to make them clearer and check each answer key on each question and there are several editorial questions that need to be corrected. In addition to obtaining comments, suggestions, and input, validity testing by experts, practitioner and student responses also provide outputs in the form of evaluation data. The results of the validity of the developed media were determined based on the results of evaluations carried out by material and assessment experts, media experts, practitioner responses, and student responses in small group trials. Data from the evaluation results from experts and product trial subjects were analyzed descriptively by looking at the average score. The results of the media validity test are presented in Table 4.

Table 4. Summary of Media Validity Test Results

\begin{tabular}{clcc}
\hline No. & \multicolumn{1}{c}{ Test Subject } & Average Score & Description \\
\hline 1 & Contents/Assessment Expert & 4.79 & Very Valid \\
2 & Learning Media Expert & 4.43 & Very Valid \\
3 & Practitioner Response & 4.65 & Very Valid \\
4 & Student Response (Small Group Test) & 4.95 & Very Valid \\
\hline
\end{tabular}




\section{Discussion}

The development research carried out resulted in an innovative learning media in the form of media fun thinkers based on HOTS questions that were focused on theme 1, the beauty of togetherness aimed at fourth grade elementary school students. With the use of media fun thinkers based on HOTS questions, it can help students understand the material that has been conveyed by the teacher in the learning process. Media fun thinkers based on HOTS questions are designed in accordance with the 2013 curriculum which is based on 21st Century learning because it emphasizes thinking skills, innovating, and collaborating in creating a problem solving including to train and develop students' higher-order thinking skills so that the information that has been conveyed by the teacher can well understood. Based on the research that has been carried out, that the HOTS question-based media fun thinkers developed have passed a series of development stages in accordance with the ADDIE model procedure, namely the analysis stage, the design stage, the development stage, and the implementation stage. Implementation), and the evaluation stage (Evaluation). The selection of the ADDIE model was based on the consideration that the ADDIE model was developed systematically based on the theoretical foundation of learning design so that it could be used as the basis for developing media with good product quality (Tegeh \& Jampel, 2017; Tegeh et al., 2015). Thus, the development of learning media using the ADDIE model is very appropriate and in accordance with the characteristics and needs (Andrajati et al., 2020; Prananda, 2020).

Based on the criteria obtained by the media fun thinkers based on HOTS questions, the criteria are very valid and suitable for use in the learning process. Therefore, in theory elementary school students are in a concrete operational phase that requires real objects in the learning process (Juwantara, 2019; Setiawan et al., 2018). So, the existence of media fun thinkers based on HOTS questions can facilitate students in carrying out the learning process because it has advantages over other print media. Media fun thinkers based on HOTS questions have advantages, namely: a) media fun thinkers based on HOTS questions are made of the best and thickest paper so they are not easily torn and damaged, b) media fun thinkers based on HOTS questions can be used by students individually or in groups, c) the use of media fun thinkers based on HOTS questions can train and develop students' higher order thinking skills, d) media fun thinkers based on HOTS questions are designed to learn while playing so that students don't get bored and stay enthusiastic (Nofrion \& Wijayanto, 2018). Furthermore, media fun thinkers based on HOTS questions are seen from the aspect of presentation, namely: a) media fun thinkers based on HOTS questions have an attractive shape with a combination of colors, textures, and appearances that are very suitable and attractive, b) there are tiles that fit together according to the squares. the box provided, c) ease of use, d) when the tiles are laid there are no obstructions.

Training on the use of media thinkers fun in elementary science learning to improve creative thinking skills supports the development of media fun thinkers books in this study so that media fun thinkers books deserve to be developed to train students' higher-order thinking skills (Agustiana et al., 2020). Previous research in his research showed that the average pretest score obtained was 58.5 and the average posttest score was 90. In this treatment there was an increase in score of 31.5\% (Kurniawati, 2017). The results of this study are in accordance with the type of learning of deaf children, namely observers, who will be interested in media that presents interesting images such as media fun thinkers. So that the media fun thinkers greatly influence the vocabulary mastery of deaf children in class VII SMPLB-B at SLB Wiyata Dharma 1 Sleman. In line with these findings, similar studies have shown that the thematic Flash Card Fun Thinkers Media is very effective in learning on Environmental Themes and shows that the development of thematic Flash Card Fun Thinkers media is effective as a supporter of scientific learning in Grade II elementary school students. (Saroh, 2016). Based on the results of previous research, it is believed that the use of media fun thinkers based on HOTS questions in the learning process can help students in growing curiosity, train and develop higher-order thinking skills and motivate students' enthusiasm for learning. Fun thinkers media can be used and utilized in the learning process, especially on theme 1 the beauty of togetherness. By utilizing the media fun thinkers are able to make the learning process very effective so that teachers need to know the characteristics of their students in class. Basically, elementary school students are theoretically in a concrete operational phase so that when students learn they need the help of objects that are concrete or real to help students more easily understand the material being studied, especially on theme 1 the beauty of togetherness. The development of fun thinkers media is able to facilitate students in learning so that learning objectives can be conveyed properly and can be achieved optimally.

\section{CONCLUSION}

Media fun thinkers based on HOTS questions for elementary school students grade IV theme 1, the beauty of togetherness developed is valid and suitable for use in the learning process. Fun thinkers 
media can be used and utilized in the learning process, especially on theme 1 the beauty of togetherness. By utilizing the media fun thinkers are able to make the learning process very effective so that teachers need to know the characteristics of their students in class. Basically, elementary school students are theoretically in a concrete operational phase so that when students learn they need the help of objects that are concrete or real to help students more easily understand the material being studied, especially on theme 1 the beauty of togetherness.

\section{REFERENCES}

Agung, A. A. G. (2014). Metologi Penelitian Pendidikan. Aditya Media Publishing.

Agustiana, I. G. A. T., Tika, I. N., \& Wibawa, I. M. C. (2020). Pelatihan Penggunaan Media Thinkers Fun pada Pembelajaran IPA SD untuk Meningkatkan Kemampuan Berpikir Kreatif. Proceeding Senadimas Undiksha.

Agustihana, S., \& Suparno. (2018). Effectiveness of Physics Mobile Learning Media to Improve Higher Order Thinking Skills of Students in Thermodynamics. Journal of Physics: Conference Series, 1097(1). https://doi.org/10.1088/1742-6596/1097/1/012031.

Andrajati, N. H., Anis, M. B., \& Mahmudi, A. (2020). Development of Online Thematic Teaching Materials Based on Higher Order Thinking Skills (HOTS) Subtheme Wealth of Energy Sources in Indonesia. IJIS Edu: Indonesian Journal of Integrated Science Education, 2(2), 152. https://doi.org/10.29300/ijisedu.v2i2.3427.

Arikunto, S. (2014). Metode Penelitian Kuantitatif, Kualitatif, dan Kombinasi (Mixed Methods). Alfabeta.

Astra, I. M., Raihanati, R., \& Mujayanah, N. (2020). Development of Electronic Module Using Creative Problem-Solving Model Equipped with Hots Problems on the Kinetic Theory of Gases Material. Jurnal Penelitian \& Pengembangan Pendidikan Fisika, 6(2), 181-194. https://doi.org/10.21009/1.06205.

Bialik, M., Bogan, M., Fadel, C., \& Horvathova, M. (2015). Character Education for the 21st Century: What Should Students Learn? Center for Curriculum Redesign.

Budiman, A., \& Jailani. (2014). Pengembangan Instrumen Asesmen Higher Order Thinking Skill (HOTS) pada Mata Pelajaran Matematika SMP Kelas VIII Semester 1. Jurnal Riset Pendidikan Matematika, 1(2), 139-150. https://doi.org/10.21831/jrpm.v1i2.2671.

Chong, E. J. M., Lim, J. S. W., Liu, Y., Lau, Y. Y. L., \& Wu, V. X. (2016). Improvement of Learning Domains of Nursing Students with the Use of Authentic Assessment Pedagogy in Clinical Practice. Nurse Education in Practice, 20, 125-130. https://doi.org/10.1016/j.nepr.2016.08.002.

Citrawathi, D. M., Adnyana, P. B., \& Santiasa, M. P. A. (2016). Analisis Kebutuhan untuk Pengembangan Modul Inkuiri Berbasis Pertanyaan (MIBP) di SMP. JPI (Jurnal Pendidikan Indonesia), 5(1), 1-11. https://doi.org/10.23887/jpi-undiksha.v5i1.8289.

Duriawati, A. D., Wasliman, I., Mulyanto, A., \& Barlian, U. C. (2020). Implementation of Literation Based Learning Information Technology (Study at MTs Alkasyaf, Mts Nurul Huda, and MTs El-Bas Ciamis). International Journal of Nusantara Islam, 8(2), 240-253. https://doi.org/10.15575/ijni.v8i2.11338.

Fanny, A. M., \& Suardiman, S. P. (2013). Pengembangan Multimedia Interaktif untuk Mata Pelajaran Ilmu Pengetahuan Sosial (IPS) Sekolah Dasar Kelas V. Jurnal Prima Edukasia, 1(1), 1. https://doi.org/10.21831/jpe.v1i1.2311.

Hajiyakhchali, A. (2013). The Effects of Creative Problem Solving Process Training on Academic Wellbeing of Shahid Chamran University Students. Procedia-Social and Behavioral Sciences, 84, 549552. https://doi.org/10.1016/j.sbspro.2013.06.602.

Ilsa, A., F, F., \& Harun, M. (2020). Pengembangan Video Pembelajaran dengan Menggunakan Aplikasi Powerdirector 18 di Sekolah Dasar. Jurnal Basicedu, 5(1), 288-300. https://doi.org/10.31004/basicedu.v5i1.643.

Jummita, J., Agustiana, I. G. A. T., \& Dibia, I. K. (2021). Media Fun Thinkers Berbasis Soal Calistung pada Tema 7 Benda, Hewan, dan Tanaman di Sekitarku untuk Siswa SD Kelas 1. Jurnal Pedagogi Dan Pembelajaran, 4(2). https://doi.org/10.23887/jp2.v4i2.37258.

Juwantara, R. A. (2019). Analisis Teori Perkembangan Kognitif Piaget pada Tahap Anak Usia Operasional Konkret 7-12 Tahun dalam Pembelajaran Matematika. Jurnal Ilmiah Pendidikan Guru Madrasah Ibtidaiyah, 9(1), 27-34. https://doi.org/10.18592/aladzkapgmi.v9i1.3011.

Kurniati, D., Harimukti, R., \& Jamil, N. A. (2016). Kemampuan Berpikir Tingkat Tinggi Siswa SMP di Kabupaten Jember dalam Menyelesaikan Soal Berstandar PISA. Jurnal Penelitian Dan Evaluasi Pendidikan, 20(2), 142-155. https://doi.org/10.21831/pep.v20i2.8058.

Kurniawati, E. S. (2017). Pengaruh Media Fun Thinkers terhadap Penguasaan Kosakata Bahasa Inggris 
Anak Tunarungu Kelas VII SMPLB-B di SLB Wiyata Dharma 1 Sleman. Jurnal Widia Ortodidaktika, 6(7), 654-664.

Lawrence, G., Ahmed, F., Cole, C., \& Johnston, K. P. (2020). Not More Technology but More Effective Technology: Examining the State of Technology Integration in EAP Programmes. RELC Journal, 51(1), 101-116. https://doi.org/10.1177/0033688220907199.

Muyaroah, S., \& Fajartia, M. (2017). Pengembangan Media Pembelajaran Berbasis Android dengan Menggunakan Aplikasi Adobe Flash CS 6 pada Mata Pelajaran Biologi. Innovative Journal of $\begin{array}{llll}\text { Curriculum } \quad \text { and } & \text { Educational 22-26. }\end{array}$ https://doi.org/https://doi.org/10.15294/ijcet.v6i2.19336.

Nofrion, N., \& Wijayanto, B. (2018). Learning Activities in Higher Order Thinking Skill (HOTS) Oriented Learning Context. Geosfera Indonesia, 3(2), 122-130. https://doi.org/10.19184/geosi.v3i2.8126.

Prananda, G. (2020). Pengembngan Media Video Pembelajaran Tema 6 Subtema 2 untuk Siswa Kelas SD Negeri 17 Pasar Masurai 1. Jurnal Dharma PGSD, 1(1), 38-45.

Primasari, I. F. N. D., \& Supena, A. (2020). Peran Orang Tua Anak Berkebutuhan Khusus (Autis) Sekolah Dasar selama Masa Covid-19. JS (Jurnal Sekolah), 5(1), 133-142. https://doi.org/https://doi.org/10.24114/js.v5i1.23309.

Rehusisma, L. A., Indriwati, S. E., \& Suarsini, E. (2017). Pengembangan Media Pembelajaran Booklet dan Video Sebagai Penguatan Karakter Hidup Bersih dan Sehat. Jurnal Pendidikan: Teori, Penelitian, dan Pengembangan, 2(9), 1238-1243.

Riani, R. P., Huda, K., \& Fajriyah, K. (2019). Pengembangan Media Pembelajaran Tematik "Fun Thinkers Book" Tema Berbagai Pekerjaan. Jurnal Sinektik, 2(2), 173-184. https://doi.org/10.33061/js.v2i2.3330.

Saroh, I. (2016). Pengembangan Media Flash Card Fun Thinkers Tematik sebagai Pendukung Pembelajaran Saintifik pada Siswa Kelas II SD N Karangtempel. Universitas PGRI Semarang.

Selman, Y. F., \& Jaedun, A. (2020). Evaluation of The Implementation of 4C Skills in Indonesian Subject at Senior High Schools. Jurnal Pendidikan Indonesia, 9(2), 244-257. https://doi.org/10.23887/jpiundiksha.v9i2.23459.

Seruni, R., Munawaoh, S., Kurniadewi, F., \& Nurjayadi, M. (2019). Pengembangan Modul Elektronik (EModule) Biokimia pada Materi Metabolisme Lipid Menggunakan Flip Pdf Professional. Jurnal Tadris Kimiya, 4(1), 48-56. https://doi.org/10.15575/jtk.v4i1.4672.

Setiawan, D. A., Wahjoedi, W., \& Towaf, S. M. (2018). Multimedia Interaktif Buku Digital 3D. Jurnal Pendidikan, 3(9), 1133-1141. https://doi.org/10.17977/jptpp.v3i9.11532.

Sugiyono. (2018). Metode Peneiltian Kuantitatif, Kualitatif, dan R\&D. In Alfabeta Bandung.

Suryatin, S., \& Sugiman, S. (2019). Comic Book for Improving the Elementary School Students' Mathematical Problem Solving Skills and Self-Confidence. Jurnal Prima Edukasia, 7(1), 58-72. https://doi.org/10.21831/jpe.v7i1.10747.

Tegeh, I. M., \& Jampel, I. n. (2017). Metode Penelitian Pengembangan. Undiksha Singaraja.

Tegeh, M., Pudjawan, K., \& Jampel, N. (2015). Model Penelitian Pengembangan. Graha Ilmu.

Tirri, K., Cho, S., Ahn, D., \& Campbell, J. R. (2017). Education for Creativity and Talent Development in the 21st Century. Education Research International, 2017, 1-2. https://doi.org/10.1155/2017/5417087.

Trilling, B., \& C., F. (2009). 21st Century Skills: Learning for Life in Our Times. Jossey-Bass.

Vince, M., \& Muhtadi, A. (2019). Pengembangan Buku Digital Interaktif Matematika pada Materi Geometri. Jurnal Inovasi Teknologi Pendidikan, 6(2), 196-207. https://doi.org/10.21831/jitp.v6i2.26809.

Widihastuti, \& Suyata. (2014). Model AFL untuk Meningkatkan Pemahaman dan Higher Order Thinking Skills Mahasiswa Vokasi Bidang Busana. Jurnal Penelitian dan Evaluasi Pendidikan, 18(2), 275289.

Winangun, I. M. A. (2020). Media Berbasis Budaya Lokal dalam Pembelajaran IPA SD. Edukasi: Jurnal Pendidikan Dasar, 1(1), 65-72.

Wisada, P. D., Sudarma, I. K., \& Yuda S, A. I. W. I. (2019). Pengembangan Media Video Pembelajaran Berorientasi Pendidikan Karakter. Journal of Education Technology, 3(3), 140. https://doi.org/10.23887/jet.v3i3.21735. 